Available online at website :

http://uinjkt.ac.id /index.php/elementar

Elementar: Jurnal Pendidikan Dasar, 1(1), 2021, 161-170

\title{
Hubungan Implementasi Pendidikan Karakter Dengan Kecerdasan Emosional Peserta Didik Dalam Mata Pelajaran PKn Kelas IV Di Masa Pandemi Covid-19
}

\author{
Hilda Hayatun Nufus ${ }^{1}$, Zikri Neni Iska ${ }^{2}$ \\ Program Studi Guru Madrasah Ibtidaiyah, Universitas Islam Negeri Syarif Hidayatullah, Indonesia \\ Jl. Ir H. Juanda No.95, Cemp. Putih, Kec. Ciputat Timur., Kota Tangerang Selatan, Banten \\ Email: hildaahytun829@gmail.com ${ }^{1}$, zikri_neni@uinjkt.ac.id ${ }^{2}$
}

\section{Corresponding}

Author: Hilda Hayatun

Nufus

Submit: 11 Agustus 2021

Revisi: 22 Desember 2021

Approve: 30 Desember

2021

Pengutipan: Hilda

Hayatun Nufus \& Zikri

Neni Iska. Hubungan

Implementasi Pendidikan

Karakter Dengan

Kecerdasan Emosional

Peserta Didik Dalam Mata

Pelajaran PKn Kelas IV Di

Masa Pandemi Covid-19.

Elementar (Elementary of

Tarbiyab): Jurnal Pendidikan

Dasar, 1(2), 2021, 161-170.

elementar.v1i2. 20891.

\section{Abstract}

The problem in this research is the lack of implementation of character education and emotional intelligence that is less developed. The purpose of this research is to determine the significant relationship between the implementation of character education on the emotional intelligence of students in the fourth grade PKN subjects at SDN Ceger 02. The type of research used is correlational research. The population in this study amounted to 63 students and the number of samples was taken based on simple random sampling technique, which was obtained by 30 students. Data collection techniques using a questionnaire (questionnaire) and instruments data collector in the form of a questionnaire with a Likert scale. Data analysis techniques in hypothesis testing using the product moment correlation formula, there is a significant relationship between the implementation of character education on emotional intelligence. The calculation results are obtained, the value of the correlation coefficient $r$ $=0.794$ means that the correlation is significant. The contribution of the implementation of character education with emotional intelligence is $88.36 \%$.

Keywords: Implementation of Character Education, Emotional Inteligence .

\section{Abstrak}

Permasalahan dalam penelitian ini adalah kurangnya pendidikan karakter dan kecerdasan emosional yang kurang terbangun. Tujuan penelitian ini adalah untuk mengetahui hubungan yang signifikan antara implementasi pendidikan karakter dengan kecerdasan emosional peserta didik dalam mata pelajaran PKN kelas IV SDN Ceger 02. Jenis penelitian yang digunakan adalah penelitian korelasional. Populasi dalam penelitian ini berjumlah 63 peserta didik dan jumlah sampel diambil berdasarkan teknik simple random sampling yaitu diperoleh 30 peserta didik. Teknik pengumpulan data menggunakan kuesioner (angket) dan instrument pengumpul data berupa angket dengan skala Likert. Teknik analisis data dalam pengujian hipotesis menggunakan rumus korelasi product moment demikian, terdapat hubungan yang signifikan antara implementasi pendidikan karakter terhadap kecerdasan emosional. Hasil perhitungan diperoleh, nilai koefisien korelasi $r=0,794$ artinya korelasi signifikan. Besar kontribusi tentang implementasi pendidikan karakter dengan kecerdasan emosional adalah sebesar 88,36\%.

Kata Kunci: Implementasi Pendidikan Karakter, Kecerdasan Emosional 


\section{PENDAHULUAN}

Dengan melihat kenyataan bahwa virus ini merebak sangat cepat, Indonesia pun tak luput menjadi negara yang terkena wabah virus tersebut, lantas pemerintah mengeluarkan perintah dan peraturan untuk dirumah saja, dan melakukan segala aktifitas dari rumah, guna untuk memutus mata rantai penyebaran virus corona. Dengan kenyataan itu pemberian pemahaman tentang pengendalian emosi diri yang semula dilakukan secara langsung namun sekarang juga harus dilakukan secara jarak jauh. Menurut (Heny:2016) apabila kecerdasan yang sifatnya intelektual (IQ) adalah sebuah "warisan" orang tua pada anak, maka kecerdasan emosional (EQ) adalah proses pembelajaran yang berlangsung seumur hidup. Maka dari itu peserta didik harus diberikan pemahaman bagaimana emosi seharusnya dikenali,dan dikontrol. Sedangkan menurut Goleman dalam (Heny:2016), emosi merujuk pada suatu perasaan dan pikiran-pikiran khasnya, suatu keadaan biologis dan psikologis dan serangkaian kecenderungan untuk bertindak.

Dengan melalui kegiatan membaca do'a sebelum belajar dan melalui pembiasaan memberi salam kepada guru sudah dilakukan sejak proses pembelajaran dilakukan secara tatap muka, sehingga pembiasan-pembiasaan yang sudah dilakukan tetap dipertahankan hingga saat ini. Kegiatan pengumpulan tugas juga peserta didik menunjukkan antusiasme dan kedisiplinannya dalam belajar meskipun dari rumah saja, sehingga pengerjaan tugas selalu dilakukan oleh peserta didik. Sikap jujur dan tanggung jawab yang dimiliki peserta didik saat proses pembelajaran disekolah diterapan dengan tidak mensontek saat mengerjakan ujian, tidak menyalin PR teman atau mengerjakannya disekolah, namun pada saat pembelajaran sekarang dilakukan dari rumah saja, peserta didik sudah tertanam karakter tersebut, sehingga meskipun peserta didik harus belajar melalui daring, mereka akan tetap melakukan pembiasaan-pembiasaan tersebut. Selain itu sikap peduli sosial kepada teman sebaya saat berada di lingungan sekolah ditunjukkan dengan saling berbagi bekal makan siang, namun karena situasi dan kondisi yang mebuat peserta didik tidak dapat saling berjumpa, kegiatan ini menjadi terhenti tetapi terdapat cara lain untuk menunjukkan kepedulian antara sesama mereka dengan melakukan saling bertanya dan memberi kabar di dalam grup belajar jika ada yang sakit, atau memberi tahukan bahwa ada tugas kepada teman yang tidak masuk mengikuti pelajaran. Hal ini dapat dilihat dari proses pembelajaran disalah satu lembaga pendidikan yaitu SDN Ceger 02.

Hal ini dapat dilihat dari proses pembelajaran disalah satu lembaga pendidikan yaitu SDN Ceger 02, pengamatan yang dilakukan pada kelas IV peserta didik yang selalu hadir mengkuti pembelajaran 
melalui Zoom meeting, memberi salam dan menjawab salam serta sapaan yang diberikan oleh guru, setelah proses belajar selesai jika mendapat tugas peserta didik kemudian mengirimkannya dengan melalui foto yang dikirimkan dan dikumpulkan ke Whats $A p p$ wali kelas, dengan kenyataan seperti itu dapar terlihat bahwa peserta didik melakukan penerapan karakter-karakter seperti karakter religius, disiplin serta tanggung jawab yang telah ditanamkan pada saat pembelajaran offline.

Namun lain daripada itu juga, tidak jarang ketika saat pembelajaran berlangsung melalui Zoom, ketika ada yang 2 diantara 24 temannya yang mencoret- coret layar tidak ada peserta didik yang mengaku melakukannya, sehingga tidak jarang menimbulkan kegaduhan dan memancing teman lainnya untuk bersuara tinggi memberi peringatan atau bahkan mengulangi hal yang sama, dan bahkan antar peserta didik terjadi saling adu mulut. Dari hal tersebut, membuat hubungan antara peserta didik dengan peserta lain kurang terbangun satu sama lain ditambah dengan adanya pembatasan untuk bertemu, dan membuat peserta didik menjadi lebih mementingkan dirinya sendiri, kurangnya pemahaman kondisi lingkungan belajar bersama dengan teman-teman lainnya tak jarang menimbulkan konflik diantaranya, sehingga menjadi mudang tersinggung, serta kurangnya pengontrolan diri dan emosi diri yang belum berjalan baik tidak jarang menimbulkan rasa kesal dan marah yang dirasakan oleh peserta didik tersebut dengan menunjukkannya melalui menggerutu atau mengomeli temannya yang bersangkutan.

Menanggapi hal tersebut, dapat terlihat bahwa penanaman karakter kepada peserta didik sudah berjalan dengan baik tetapi tetap perlu adanya pengembangan dan juga upaya untuk mempertahankannya, namun untuk emosi peserta didik terlihat masih belum stabil dalam mengenali emosi dan mengendalikannya. Oleh karenanya, melalui pendidikan karakter dapat menjadi salah satu cara penyembuh penyakit sosial. Pendidikan karakter yang ada di sekolahsekolah dapat ditunjang dalam mata pelajaran PKn.

Pendidikan kewarganegaraan (PKn) merupakan salah satu mata pelajaran yang dipelajari oleh peserta didik sekolah dasar, di dalam mata pelajaran PKn terdapat penjelasan yang memberikan pemahaman tentang karakter baik dan terdapat normanorma yang ada disetiap materi pelajarannya. Pendidikan karakter menurut (Yaumi:2014) adalah sebuah usaha yang dilakukan secara sengaja oleh sekolah dan pemerintah (daerah dan pusat) guna menerapkan nilai-nilai etis seperti kepedulian, kejujuran, keadilan, tanggung jawab, dan penghargaan terhadap orang lain. Berkaitan dengan hal tersebut, (Fauzan) mengungkapkan, Goleman menerangkan bahwa keberhasilan seseorang di masyarakat, ternyata $80 \%$ dipengaruhi 
oleh kecerdasan emosi dan hanya 20\% ditentukan oleh kecerdasan otak (IQ). Emosi dapat diklasifikasikan menjadi dua yaitu, emosi positif maupun negatif. Santrock mengungkapkan bahwa emosi dipengaruhi oleh dasar biologis dan juga pengalaman masa lalu. Perkembangan emosi pada masa kanak-kanak awal ditandai dengan munculnya emosi evaluatif yang disadari rasa bangga, malu, dan rasa bersalah, di mana kemunculan emosi ini menunjukkan bahwa anak sudah mulai memahami dan menggunakan peraturan dan norma sosial untuk menilai perilaku mereka. (Femmi:2015) Goleman dalam (Olivia:2019) menyebutkan bahwa kecerdasan emosional mengacu pada kapasitas untuk mengenali perasaan diri sendiri dan orang lain, untuk memotivasi diri sendiri, dan mengelola emosi dengan baik dalam diri kita sendiri dan dalam hubungan dengan orang lain.

Menurut (Heny:2016) menerangkan bahwa agar kualitas pendidikan dapat tercapai secara optimal, perlu diupayakan bagaimana membina peserta didik untuk memiliki kecerdasan emosi yang stabil sebagai penyeimbang dari inteligensi yang ada. Sebab, melalui kecerdasan emosional peserta didik dapat memahami diri dan lingkungannya secara tepat, memiliki rasa percaya diri, tidak mudah putus asa, dan dapat membentuk karakter peserta didik secara positif. Dengan pemaparan tesebut maka dapaat diidentifikasi bahwa terdapat masalah pada 1. pengontrolan emosi yang ada pada diri peserta didik, 2. Pesera didik yang mementingkan dirinya sendiri, serta 3 . Kecerdasan emosi peserta didik yang masih terbilang rendah. Melihat kenyataan tersebut penelitian ini dilakukan untuk mengetahui hubungan yang signifikan antara implementasi Pendidikan karakter dengan kecerdasan emosional peserta didik kelas IV dalam mata pelajaran PKn dimasa pandemi covid-19. Dan kecerdasan emosional menurut Cooper dan Sawaf dalam (Al. Tridonanto : 2013 ) mengatakan bahwa kecerdasan emosional adalah kemampuan merasakan, memahami, dan secara selektif menerapkan daya dan kepekaan emosi sebagai sumber energi dan pengaruh yang manusiawi.

Penelitian ini juga diharapkan dapat menambah wawasan bagi guru, sekolah, orang tua, masyarakat, dan peserta didik itu sendiri dalam upaya mengimplementasikan Pendidikan karakter dalam mata pelajaran PKn agar kecerdasan emosional peserta didik dapat meningkat di masa pandemi ini.

\section{METODE PENELITIAN}

Penelitian ini menggunakan metode kuantitatif - koreasional. menurut Gay dalam Sukardi (Ninit:2018), penelitian korelasi adalah suatu penelitian yang melibatkan tindakan pengumpulan data guna menentukan apakah ada hubungan dan tingkat hubungan antara dua variabel atau lebih. 
Hubungan Implementasi Pendidikan Karakter Dengan Kecerdasan Emosional Peserta Didik ...

Populasi pada penelitian ini berjumlah 63 orang peserta didik kelas IV SDN Ceger Teknik pengambilan sampel dilakukan dengan teknik simple random sampling. Simple random sampling adalah Teknik untuk mendapatkan sampel yang langsung dilakukan pada unit sampling. Cara pengambilan sampel dengan simple random sampling dapat dilakukan dengan metode undian, ordinal, maupun tabel bilangan random. (I Putu Ade : 2018) Dengan menggunakan teknik simple random sampling, maka peneliti menetapkan sebanyak 30 peserta didik yang berasal dari kelas IV A dan IV B sebagai responden.

Teknik pengumpulan data dengan menggunakan instrument angket yang terdiri dari 45 item soal, dengan 25 item soal variable implementasi Pendidikan karakter dan 20 item soal kecerdasan emosional. Angket yang digunakan oleh peneliti sebagai alat untuk mengukur ubungan antara implementasi Pendidikan karakter dengan kecerdasan emosional peserta didik.

Peneliti menggunakan uji validitas dan uji reliabilitas untuk mengukur angket tersebut. Uji validitas yang digunakan oleh peneliti adalah korelasi product moment dengan taraf signifikansi 0.05. Arikunto dalam (Agustina:2020) yang menyatakan bahwa validitas merupakan alat ukur yang menunjukkan valid dan sahihnya suatu instrumen penelitian. Tujuan dilakukan uji validitas adalah untuk memastikan bahwa item-item pertanyaan/pernyataan pada kuesioner dan wawancara tersebut valid/sah untuk digunakan sebagai alat ukur variabel penelitian yang sedang dilakukan. Setelah melakukan uji validitas, maka didapatkan hasilnya 17 dari 25 item soal yang valid variable implementasi pendidikan karater dan 14 dari 20 item soal pernyataan variable kecerdasan emosional.

Uji reliabilitas peneliti menggunakan cronbach's alpha. Menurut Azwar, dalam (Agustina:2020) uji reliabilitas adalah sejauh mana suatu hasil pengukuran dapat dipercaya. Instrumen dikatakan reliabel jika dapat digunakan untuk mengukur variabel berulangkali yang menghasilkan data yang sama atau hanya sedikit bervariasi. menurut besarnya koefisien korelasi reliabilitas dapat dilihat sebagai berikut (Herlina:2019).

1. Cronbach's $A$ lpha $<0,50=$ reliabilitas rendah.

2. Cronbach's $A$ phba $<0,51 \tilde{n} 0,70=$ reliabilitas moderat

3. Cronbach's Alpha $0,71 \tilde{n} 0,90=$ reliabilitas tinggi

4. Cronbach's Alpha $>0,90=$ reliabilitas sempurna

Berdasarkan perhitungan yang telah dilakukan, didapatkan hasil, angket untuk variable implementasi Pendidikan karakter sebesar 0,842 dan besarnya nilai untuk angket kecerdasan emosional sebesar 0,756 dan kedua nilai tersebut termasuk kedalam kategori reliabilitas yang tinggi.

Teknik analisis data yan digunakan 
oleh peneliti adalah analisis deskriptif dan analisis inferensia. Untuk teknik analsis data deskriptif peneliti mencari nilai mean, median, modus, frekuensi, persentasi, dan sebagainya. Sedangkan untuk teknik analisis statistik inferensia, peneliti akan melakukan uji normalitas dan uji linearitas sebagai uji prasyarat untuk mengkonfirmasi apakah antara kedua variabel berdistribusi normal dan memiliki hubungan linieritas atau tidak. Peneliti menghitung uji normalitas menggunakan teknik saphiro wilk. Kemudian peneliti akan melakukan uji hipotesis dengan menggunakan korelasi product moment untuk membuktikan ada atau tidaknya hubungan yang positif dan signifikan antara implementasi pendidikan karakter dengan kecerdasan emosional peserta didik dengan melihat $\mathrm{r}$ hitung $>\mathrm{r}$ tabel.

Bentuk hipotesis statistik pada penelitian ini adalah sebagai berikut: $\mathrm{H} 0: \mathrm{r}_{\mathrm{xy}}$ $=0$ yang berarti tidak terdapat hubungan $\mathrm{H} 1$ : rxy $\square 0$ yang berarti terdapat hubungan antara implementasi Pendidikan karakter dengan kecerdasan emosional peserta didik kelas IV SDN Ceger 02 Kemudian peneliti menggunakan rumus sebagai berikut untuk mencari kontribusi variabel $\mathrm{X}$ terhadap variabel Y (Mukhtazar:2012) :

\section{$\mathrm{KD}=r^{2} \mathrm{X} 100 \%$}

Keterangan :

$\mathrm{KD}=$ Kontribusi variabel $\mathrm{X}$ terhadap Variabel Y r2 = Koefisien korelasi antara variabel $\mathrm{X}$ dan variabel $\mathrm{Y}$

Peneliti menghitung analisis deskriptif dan analisis statistik inferensia menggunakan aplikasi IBM SPSS Statistics 20.

\section{HASIL DAN PEMBAHASAN}

Penelitian ini dilakukan dengan tujuan untuk mengetahui hubungan implementasi pendidikan karakter dalam mata pelajaran PKN dengan kecerdasan emosional peserta didik kelas IV SDN Ceger 02. Melalui hasil angket variable implementasi pendidikan karakter yang disebar kepada 30 responden peneliti mendapatkan data nilai rata-rata (mean) implementasi pendidikan karakter peserta didik sebesar 109.10, nilai tengah (median) berada pada angka 111.00, nilai yang sering muncul (modus) 112, kemudian nilai standar deviasi 8.264, nilai variance sebesar 68.300, selanjutnya nilai range 34 , minimum 90 , dan maximum 124. Dan hasil perolehan dari kategorisasi data implementasi pendidikan karakter memiliki nilai tertinggi pada indikator bersikap religius sebesar 83,25\% dengan kategori sangat kuat. Sedangkan nilai terendah pada indikator menanamkan sikap peduli sosial dengan hasil persentase sebesar $80,50 \%$ yang termasuk kedalam kategori kuat. Hal tersebut menandakan bahwa peserta didik dapat menerapkan karakter religius dengan sangat baik selama masa pembelajaran pandemi jarak jauh. 
Selain itu hasil dari angket variable kecerdasan menunjukkan hasil data nilai ratarata (mean) kecerdasan emosional peserta didik sebesar 80,27, nilai tengah (median) berada pada angka 82.00, nilai yang sering muncul (modus) 85, kemudian nilai standar deviasi 6.705, nilai variance sebesar 44.961, selanjutnya nilai range 24 , minimum 67 , dan maximum

Dan hasil kategorisasi data kecerdasan emosional didapatkan memiliki nilai tertinggi pada indikator memotivasi diri yang sangat kuat sebesar $77,81 \%$. Sedangkan nilai terendah dengan besar persentase $70,93 \%$ dengan kategori kuat terdapat pada indikator memahami hubungan dengan orang lain. Hal ini menjelaskan bahwa peserta didik dapat mengelola emosi diri dengan amat baik ketika mereka sadar jika sedang dalam keadaan yang emosi.

Berdasarkan hasil perhitungan terhadap 30 sampel data dengan menggunakan teknik Shapiro wilk test pada program IBMSPSS statistics 20, diperoleh hasil menunjukkan nilai signifikansi implementasi pendidikan karakter sebesar (p) 0,695 dan nilai signifikansi kecerdasan emosional sebesar (p) 0,196 maka dapat disimpulkan bahwa data yang diuji berasal dari populasi yang berdistribusi normal. Dengan ini dapat dikatakan bahwa data implementasi Pendidikan karakter dan kecerdasan emosional berdistribusinormal.

Setelah melakukan perhitungan dengan uji linearitas, maka didapatkan hasil sebagai berikut, angka pada deviation from linearity sebesar 0.794, hal ini membuktikan bahwa nilai sig $>0.05$, sehingga hubungan antara implementasi Pendidikan karakter dan kecerdasan emosional bersifat linear.

Hasil uji analisis uji hipotesis dengan menggunakan korelasi product moment, didaptkan hasil sebagai berikut :

\section{Tabel 1. Hasil Uji Hipotesis}

\section{Correlations}

\begin{tabular}{|cc|r|r|}
\hline & & $\begin{array}{r}\text { Implementa } \\
\text { si }\end{array}$ & Kecerdasan \\
\hline & Pearson & 1 & $.940^{* *}$ \\
$\begin{array}{c}\text { Implem } \\
\text { en }\end{array}$ & Correlation & & \\
tasi & Sig. (2-tailed) & & .000 \\
& $\mathrm{~N}$ & 30 & 30 \\
Kecerda & Corrson \\
s & Sig. (2-tailed) & $.940^{* *}$ & 1 \\
an & $\mathrm{N}$ & .000 & \\
& & 30 & 30 \\
\hline
\end{tabular}


Dilihat dari tabel tersebut, bahwa nilai $\mathrm{r}$ hitung atau pearson correlation $=$ 0,940 dengan nilai signifikansi 0,000 . Jika dilihat berdasarkan teori, interpretasi korelasi dapat dilihat dari perolehan $\mathrm{r}$ hitung > r tabel. Besarnya nilai $r$ tabel yang diperoleh adalah 0,361 dengan nilai $\mathrm{df}=$ 30-2 = 28. Hasil perolehan tersebut menunjukan bahwa $0,940>0,361$ dengan nilai sig $0,000<0,05$. Dengan demikian, dapat disimpulkan bahwa $\mathrm{H} 0$ ditolak atau terdapat hubungan yang signifikan antara implementasi pendidikan karakter terhadap kecerdasan emosional peserta didik dalam mata pelajaran PKN kelas IV SDN Ceger 02 di masa pandemic dengan tingkat hubungan tinggi. Kemudian, berdasarkan perhitungan koefisien determinan besarnya kontribusi implementasi pendidikan karakter terhadap kecerdasan emosional adalah sebesar $88,36 \%$ dengan perhitungan $\mathrm{KD}=$ r2 $\times 100 \%$ atau $\mathrm{KD}=(0,940 \times 0,940) \times 100$ $=88,36 \%$

Dari hasil perhitungan dan analisis diatas, dapat disimpulkan bahwa $\mathrm{H} 1$ diterima atau dapat dikatakan terdapat hubungan yang positif dan signifikan antara implementasi pendidikan karakter dengan kecerdasan emosional peserta didik kelas IV SDN Ceger02.

Berdasarkan hasil perhitungan yang sudah dilakukan oleh peneliti, sejalan dengan hasil yang didapatkan dari perhitungan implementasi karakter dengan hasil penelitian M. Zainul Labib Universitas Islam Negeri Syarif Hidayatullah Jakarta dalam penelitiannya metode kualitatif deskriptif dengan judul 'Implementasi Pendidikan Karakter dan Pengaruhnya Terhadap Perilaku Akademik Siswa Kelas IV SD Negeri 1 Jombang Ciputat' pada temuan penelitiannya menunjukkan bahwa implementasi pendidikan karakter pada peserta didik, di indikator religius memiliki angka yang tinggi, seperti pada salah satu contoh pada item soal melaksanakan ibadah tepat pada waktunya, terdapat sebanyak 22 responden atau 73,3\% menjawab selalu dan 8 responden atau $26 \%$ menjawab sering.

Dan dari hasil perolehan perhitungan kecerdasan emosional, terdapat penelitian terdahulu yang mempekuat penelitian ini yaitu Khanif Maksum pada jurnal Universitas nya yang berjudul 'Hubungan Kecerdasan Emosional Dan Motivasi' hasil penelitiannya menunjukkan bahwa terdapat hubungan antara kecerdasan emosional siswa dengan motivasi, Temuan dan hasil penelitian menunjukkan bahwa kecerdasan emosional siswa tergolong mempunyai kategori yang tinggi yaitu sebesar 51\%, motivasi belajar tergolong dalam 
kategori yang sangat tinggi yaitu sebesar $49 \%$.

\section{SIMPULAN}

Dari hasil penelitian yang didapatkan dan melalui proses analisis data, dan pembahasan yang telah dijelaskan pada bab sebelumnya, kemudian dapat diambil kesimpulan bahwa penelitian ini menunjukkan adanya hubungan yang signifikan antara implementasi pendidikan karakter dengan kecerdasan emosional, serta adanya signifikanyang kuat dengan perolehan $\mathrm{r}$ hitung atau pearson correlation sebesar 0,940, besarnya nilai $\mathrm{r}$ tabel yang diperoleh adalah 0,361 dengan nilai $\mathrm{df}=30-2=$ 28. Hasil perolehan menunjukan bahwa 0,940 >0,361 dengan nilai sig $0,000<0,05$. Besar nilai koefisien determinasi pada penelitian ini menunjukkan angka 88,36\% dan sisanya sebesar 11,64\% dipengaruhi faktor lain yang tidak dibahas dan dimuat dalam penelitian ini. sehingga hasilnya menunjukkan terdapat hubungan yang signifikan antara implementasi pendidikan karakter dengan kecerdasan emosional dalam mata pelajaran PKN pada peserta didik kelas IV SDN Ceger 02 di masa pandemi.

\section{DAFTAR PUSTAKA}

Adhim, Fauzan. Hubungan Pendidikan Karakter Terhadap Kecerdasan Emosional Pada Mahasiswa Fakultas Ekonomi Universitas Kanjuruhan Malang. (Jurnal Inspirasi Pendidikan : Universitas Kanjuruban Malang)

Alfianika, Ninit. Buku Ajar Metode Penelitian Pengajaran Bahasa Indonesia. Yogyakarta

: Deepublish Publisher. 2018.

Herlina, Vivi. Panduan Praktis Mengolah Data Kuesioner Menggunakan SPSS. Jakarta : PT. Elex Media Computindo. 2019

Marzuki, Agustina. Crystha Armereo, Pipit Fitri Rahayu. Praktikum Statistik. Malang : Ahlimedia Press. 2020.

Mukhtazar. Teknik Penyusunan Skripsi. Yogyakarta : Absolute Media. 2012. Nurmalitasari, Femmi. Perkembangan Sosial Emosi pada Anak Usia Prasekolah. (Buletin

Psikologi : Fakultas Psikologi Universitas Gadjah Mada Volume 23, No. 2). 2015

Payadnya, I Putu Ade Andre. dan I Gusti Agung Ngurah Trisna Jayantika. Panduan Penelitian Eksperimen Beserta Analisis Statistik dengan SPSS. Yogyakarta: Deepublish. 2018.

Perbowosari,Heny. Peran Kecerdasan Emosional Dalam Pendidikan Karakter.Seminar Nasional : Institut Hindu Dharma Negeri Denpasar 
Hilda Hayatun Nufus \& Zaenul Slam

bekerjasama dengan Jayapangus

Pres.2016.

Tridonanto, Al. dan Baranda Agency.

Melejitkan Kecerdasan Emosi (EQ) buah

bati.

(Jakarta : PT. Elex Media Computindo). 2013.

Wuwung, Cherly Olivia. Strategi Pembelajaran

dan Kecerdasan Emosional, Surabaya :

Scopindo. 2019.

Yaumi, Muhammad. Pendidikan Karakter :

Landasan, Pilar dan Implementasi.

(Perpustakaan Nasional : Katalog

Dalam Terbitan). 2014. 